Ijtihad: Jurnal Wacana Hukum Islam dan Kemanusiaan Vol. 20, No. 1 (2020), pp. 1-21, doi : 10.18326/ijtihad.v20i1.1-21

\title{
Waqf fundraising strategy for Islamic boarding's independence
}

\author{
Mohammad Noviani Ardi \\ Universitas Islam Sultan Agung (UNISSULA) Semarang \\ E-mail:mn.ardi@unissula.ac.id
}

\section{Dina Yustisi Yurista}

Universitas Wabid Hasyim Semarang (UNWAHAS)

E-mail:dina_yurista@unwahas.ac.id

\section{Suci Ramadhan}

Universitas Islam Negeri (UIN) Syarif Hidayatullah Jakarta

E-mail:suciramadhan95@gmail.com

DOI: 10.18326/ijtihad.v20i1.1-21

The purpose of this article is to find out the fundraising of waqf fund strategy conducted by Tazakka, Modern Boarding School, also to know how effective the implementation of these strategies in realizing the independence of this boarding school. This research uses quantitative research with descriptive approach that relies on primary data sourced from interviews. This article interpreted the management of waqf funds in Tazakka Boarding School which consist the procedures of waqf association and effectiveness of waqf fund management to realize the independence of boarding school. Moreover, these findings reveal that the effective mechanisms involved in raising waqf funds, in turn, lead to the enhancement of the roles and functions of waqf institutions to build modern educational institutions today.

Tujuan dari artikel ini adalah untuk mengetahui strategi fundraising wakaf yang diterapkan oleh Pondok Pesantren Modern Tazakka dan untuk mengetahui sejauh mana efektifitas penerapan strategi tersebut dalam mewujudkan kemandirian pesantren modern Tazakka Bandar Batang. Artikel ini merupakan penelitian kuantitatif dengan pendekatan deskriptif yang menggunakan data primer 
ljtihad: Jurnal Wacana Hukum Islam dan Kemanusiaan, Volume 20, No. 1, Juni 2020: 1-21

bersumber dari wawancara. Artikel ini menjelaskan tata kelola dana wakaf di Pondok pesantren Tazakka yang mencakup tata cara perhimpunan wakaf dan efektifitas sistem pengelolaan dana wakaf (fundraising) untuk mewujudkan kemandirian pesantren. Selain itu, penelitian ini mengungkapkan mekanisme yang efektif dalam peningkatan dana wakaf, terutama pada peran dan fungsi lembaga wakaf yang produktif guna mencapai kemandirian lembaga pendidikan pesantren di era modern saat ini.

Keywords: Boarding School; Tazak.ka; Waqf

\section{Introduction}

Waqf is one of the activities in Islamic economics that aims to build the welfare of the ummah (Baidhawy, 2007). In the terms of Islamic economic, waqf is a kind of gift which is carried out by holding ownership of origin, then making the benefits in accordance with the people who give endowments (waqif) without compensation (Wakaf, 2007).

The history of waqf development in Indonesia is in line with the spread of Islam throughout the archipelago. In addition, to carry out Islamic da'wah, the scholars also taught waqf to Muslims. Therefore, the need for places of worship such as mosques, surau encourages Muslims to surrender their land as waqf (Rozalinda, 2010). So, the waqf assets in Indonesia are mostly in the form of land which is traditionally carried out by the community (nadzir) (Hidayatullah, 2003). Along with the social development of the Islamic community, the practice of representatives is progressing step by step. The waqf tradition for places of worship persists and other endowments arise for educational activities such as for the establishment of Islamic boarding schools (M. Huda, 2015).

Islamic boarding schools are the oldest educational institution in Indonesia that has been established and developed especially in Javanese land since the $17^{\text {th }}$ century. The existence of Islamic boarding schools aims to understand, appreciate and practice the teachings of Islam by emphasizing the importance of Islamic morality as a guideline for daily life (Direktorat Pengembangan Zakat dan Wakaf Indonesia, 2004). To achieve the objectives of the Islamic boarding school, adequate facilities and infrastructure are needed such as mosques, buildings, and so on. Therefore, waqf funds can be used as a potential source of funds in the framework of the independence of the Islamic boarding school.

The establishment of the Tazakka Foundation and the birth of the Tazakka Boarding 
School are inseparable. Since its inception, the Tazakka Foundation, located in Bandar Subdistrict, Batang Regency, Central Java, has dedicated itself in three fields, namely; preaching, social, and education. In the field of education, the Tazakka Foundation established Pondok Modern Tazakka (Tazakka Modern Boarding School) on September 6, 2009 which was packaged in a grand gathering and breaking the fast with the Muslims by inviting scholars, religious leaders and the community. The activities held on the ground would be the establishment of the lodge which was attended by around 1,500 worshipers. On that occasion also held a waqf fundraising for the release of cottage land. The enthusiasm of the community towards the waqf movement turned out to be very high, as evidenced in a short period of time around IDR 900 million. Since then, the encouragement of the community to immediately realize the establishment of modern Islamic boarding schools in Bandar, Batang has been stronger by jointly contributing all of its potential so that the waqf movement begins to resonate for the construction of the Tazakka boarding School (Tazakka, 2015). Therefore, the purpose of this paper is to find out the fundraising of waqf fund strategy conducted by Tazakka, Modern Boarding School, also to know how effective the implementation of these strategies in realizing the independence of this boarding school.

\section{Methodology}

This study uses qualitative research with a descriptive approach, to describe the waqf fundraising strategy carried out at the Tazakka Islamic boarding school. This study uses primary and secondary data sources with interviews and documentation as a method of data collection, then analyzed by editing, classifying, analyzing and concluding processes.

\section{Literature review waqf}

(Ibrahim, Amir, and Masron, 2013) stated waqf is the act of holding certain property and preserving it for the limited benefit of certain philanthropy which prohibits the use or disposition of anything other than specific objectives. Likewise, waqf serves as a means to finance the Islamic community. In addition, (Aziz and Yusof, 2014) defines endowments as holding malls (assets) and preventing their consumption for the purpose of repeatedly extracting waqf. use for the purpose of goals that represent truth or generosity. 
Ijtihad: Jurnal Wacana Hukum Islam dan Kemanusiaan, Volume 20, No. 1, Juni 2020: 1-21

However, (Md. Shahedur Rahaman Chowdhury, 2011) write that waqf is not only spiritual and religious aspects but also important issues that have an influence on economic, political, community, educational and social development. Because waqf institutions cover a variety of issues ranging from the economy to the social aspects of human development, it can be linked as one of the main tools for elevating the pride, dignity and supremacy of Islam. while according to the Indonesian Government Regulation in Republic of Indonesia Law No.41 of 2004 stated waqf is a legal act of waqif to separate and surrender a portion of his property to be used forever in a certain period of time in accordance with his needs for worship and general welfare according to sharia (Efendi, 2019; Nice Durroh, 2016).

The arguments on which the waqf teachings form the basis are derived from the understanding of the texts of the verses of the Qur'an and the Sunnah. However, there is no verse of the Qur'an that explicitly explains about waqf (Djunaidi, and Al-Asyhar, 2006). However, there are a number of verses of the Qur'an which are interpreted by scholars as the basis of waqf law, especially those that discuss the giving of assets in providing guidance and can be used as a source of legal representation (N. Huda, 2009). The verses of the Qur'an are as follows:

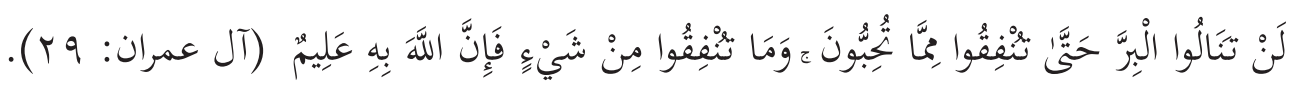

"You will not get the virtue (perfect) before you infuse some of the assets you love. And whatever you inflict on it, truly, Allah is omniscient. "(al-Imran: 92)

The above verse becomes the proof, He recalls waqf based on the history of Abu Talha when he heard the verse, he rushed to endow some of the assets he loved, namely a garden famous for its fertility. The Prophet advised him to make his gardening a waqf, then Abu Talha followed the advice of the Prophet.

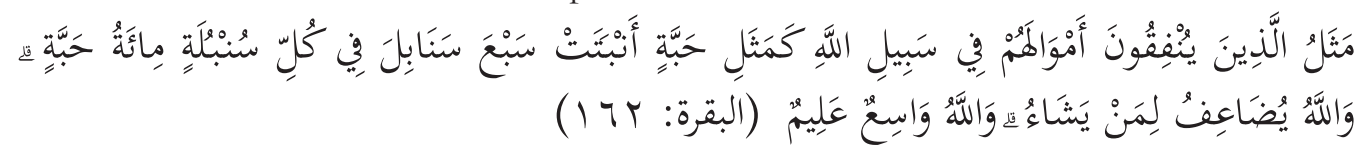

"The parable of those who infuse their wealth in the way of Allah is similar to a seed that grows seven stems, on each stalk, grows a hundred seeds. God folds the reward for whoever he wants. And Allah is the breadth of His gift, the Knower." (QS Al-Baqarah: 261)

This verse explains that those who spend their wealth in the way of Allah will multiply their reward to seven hundred-fold, and among the acts of spending wealth in the way of 
Allah is endowments.

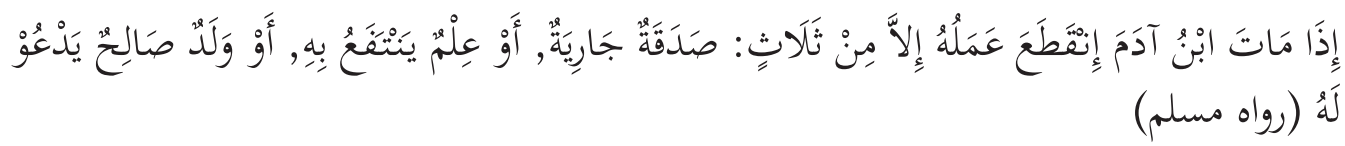

"If a man dies, his deeds are interrupted, except for three things, namely of charity alms, or the knowledge that is utilized, or the pious child who prays for him. (H.R Muslim)"

The scholars interpret the words of charity alms (alms which will continue to flow reward) in the hadith with the waqf. Therefore, endowments are virtues that are fixed and will not be interrupted. That is, even though the waqf has passed away, he will still get the reward from Allah provided that the assets he represents are still able to continue to provide benefits to others.

The scholars differed in determining the pillars of waqf because of the implications of their differences in viewing the substance of waqf (M. Huda, 2015). Endowments are declared valid if the pillars have been fulfilled and the conditions. Pillars of waqf according to the majority figh are four types, namely:

1. Waqif (the founder)

2. Mawquf 'alaih (beneficiaries)

3. Mawquf (the waqf asset)

4. Shigat or Iqrar (expression)

Some general requirements that must be considered in carrying out waqf are among others (Alabij, 1989):

1. The purpose of waqf must not conflict with the interests of Islam.

2. Do not give a certain time limit in the representative.

3. Not forgiving goods that become a prohibition of Allah that can cause slander.

4. If waqf is given through a will, which is only carried out after the waqif dies, then the amount or value of the assets represented should not be more than $1 / 3$ part of the maximum amount.

\section{The concept of fundraising}

The most important and initial governance mechanism is to collect waqf property from the waqif, known as fundraising activities (M. Huda, 2015). Fundraising is defined as the 
conceptual framework of an activity in order to raise funds and other resources from the community that will be used to finance the program and operational activities of the institution so as to achieve the objectives (Juwaini, 2005). Fundraising can also be interpreted as a concept in an effort to develop social enterprises (Suparman, 2009).

Fundraising is closely related to the ability of individuals, organizations, and legal entities to invite and influence others so as to raise awareness, concern and motivation for donations (M. Huda, 2011). In that context, fundraising management for institutions is important and requires appropriate management analysis.

The purpose of fundraising according to (Juwaini, 2005) is as follows:

1. The main purpose of fundraising is to raise funds and power the operation of the institution. Without fundraising activities, the activities of the management institution will be less effective or can be said to fail despite other successes because if fundraising does not result means there are no resources that cause the institution to lose the ability to continue to maintain the continuity of the program.

2. The second objective of fundraising is to add prospective donors or increase the donor population. Institutions that do fundraising must continue to increase the number of donors. To be able to increase the number of donations, it can be done in two ways, namely: adding donations from each donor or adding new donors.

3. Fundraising activities carried out by an institution will affect the image of the institution. This image is designed so that it can have a positive impact

4. The fourth objective is to satisfy donors. This goal is the highest goal and long-term value, even though the implementation of activities is carried out technically on a daily basis. Satisfaction of donors will affect the value of donations that will be given (M. Huda, 2015).

Fundraising substance according to (Suparman, 2009) is divided into three things, namely: motivation, programs, and methods. Motivation is defined as a series of knowledge, values, beliefs, and reasons that encourage prospective donors to spend part of their wealth. Within this framework, institutions must continue to carry out education, socialization, promotion and transfer of information so as to create awareness and needs for potential donors (M. Huda, 2015). 
The substance of fundraising is in the form of programs, namely activities from the implementation of a clear vision and mission of the institution so that the community is able to be moved to carry out philanthropic actions. In this case, the institution can develop the program by making program cases, conducting segmentation research for prospective donors, determining techniques that can be used to mobilize these resources or funds, and conducting overall monitoring of both the process, effectiveness and results (Sutisna 2008). In the process of achieving the desired program, a long-term strategy program plan needs to be formulated specifically and systematically. Planning to raise funds or power associated with the program is an integrated planning program. This method allows the institution to achieve the specified change targets by looking at the stages of progress over time (Widjajanti, 2008; M. Huda, 2013).

There are several simple techniques that can be used to design strategic planning especially in fundraising or power by institutions (M. Huda, 2015). The analytical technique that can be used is Strength-Weakness-Opportunity-Threat (SWOT) analysis which is very important for an institution to consider. By conducting a SWOT analysis, an institution can develop fundraising methods, find ways to avoid weaknesses, reach open opportunities, and develop ways to overcome emerging threats (Norton, 2002).

In compiling and implementing this strategy, an institution must certainly apply strategic principles, which are always economical, linking fundraising with institutional priorities, keeping costs lower than income, and avoiding risks (Tjiptono and Diana, 2003). Then, to achieve positive fundraising or power, tests, evaluations, and controls are needed. This is important because donors, the community and the advisory board will ask for the results obtained (M. Huda, 2015).

\section{Islamic boarding school}

According to (Yacub, 1985), Islamic boarding schools mean Islamic educational institutions which are generally non-classical, instructors who have Islamic knowledge through classical Islamic books with Arabic writing in ancient Malay or Arabic. The books are usually the work of Islamic (Arabic) scholars in medieval times. Whereas (Gontor, 1978) defines Islamic boarding schools as Islamic religious education institutions with dormitory or 
Ijtihad: Jurnal Wacana Hukum Islam dan Kemanusiaan, Volume 20, No. 1, Juni 2020: 1-21

cottage systems (pesantren), where the kyai as the central figure, the mosque as the centre of activities that animates it, and Islamic teaching under the guidance of the leader of pesantren (kyai) which is followed by student in pesantren (santri) as its main activity.

Islamic boarding schools as educational institutions remain stable and consistently carry out their roles as centres for the deepening of the religious sciences and Islamic missionary (da'wab) institutions as well as participating in educating the nation have been recognized by the public, as evidenced by their success in printing religious leaders, nation fighters and community leaders. This is clear evidence that Islamic boarding schools have contributed a lot in building the Indonesian nation (Zarkasyi, 2005; M. Huda, 2013).

\section{Result and analysis}

Implementation of waqf funds at tazakka islamic boarding school

The management of waqf in Tazakka Boarding School is carried out by the management of waqf (nadzir) waqf of Tazakka. Nadzir waqf of Tazakka empowers waqf management which is divided into three main stages, namely (Ardi, 2017):

1. Stages of collecting waqf;

2. Stages of waqf management;

3. Stages of utilizing waqf;

Collection is an important process considering that the source of waqf is basically derived from the collection of waqf assets and at the same time becomes the initial foundation in the development of management of waqf assets. The Tazakka waqf collection is divided into 2 parts, namely marketing strategies and fundraising strategies. Tazakka's marketing strategy is carried out through the presentation of development programs and cottage development in the form of socialization and waqf education to the community.

The socialization and education carried out is intended so that the community understands more about the primacy of waqf as well as the procedures for representing and distributing it as existing in the books of figh. This will make it easier even to form the mindset and lifestyle of the community to carry out waqf movements. The media marketing used in socializing the waqf is through leaflets, brochures, Tazakka monthly mini-newspapers with 3000 copies of publishing, and other printed and electronic media. Also included is the 
site mwm:tazakka.orid as the official website of Pondok Modern Tazakka, and social media such asTazakka's officialTwitter account,@PondokTazakka, Instagram@PondokTazakka,@ Tazakka fanpage and so on. Besides that, there is also an SMS Masking service, namely short text message (SMS) programmed specifically with sender-IDs in the name of Tazakka so that the congregation understands if they receive an SMS text with the Tazakka sender, it means that the SMS text is from the official admin of Tazakka.

In addition to being used for information media about cottage activities, this SMS is also used as a media marketing for waqf products and zakat in Tazakka. Another marketing strategy is to provide a zakat organization namely LAZIS Tazakka counter in the foyer of Az-Zaky Mosque. This aims to facilitate the endowments in distributing waqf given the high intensity of public awareness activities at the Az-Zaky Mosque. In addition to functioning as a zakat and waqf counter teller, this counter also serves as a place to consult between the endowment and the management of LAZISWAF Tazakka.

Fundraising strategies carried out by LAZISWAF Tazakka Tazakka are carried out in several ways and approaches, including: (Ardi, 2017; Hudaya, 2016)

1. Identify prospective candidates.

Identification of candidates for waqif covers the area and assumptions about the potential amount of waqf. This process becomes important for nadzir waqf of Tazakka to map the aspirant candidates and then it will be easier to carry out waqf guidance and dedication to be right on target.

2. Strategy of proactive service.

This method is done by nadzir waqf of Tazakka if the pilgrims have not been able to deliver directly to Tazakka or have not been able to use waqf services such as account transfers or auto debit. This proactive service is 24-hour service, opened every day including holidays and red dates. It is intended that the prospective beneficiary responds well to the waqf services performed by Tazakka, and so as not to procrastinate from giving away their assets.

3. Endowment through the auto debit facility.

The auto debit facility or known as transferring balances automatically from the customer's account to the bank. In this case, the waqf auto debit facility used by Tazakka 
is the service of a partner bank that facilitates customers to automatically transfer their accounts to the Tazakka waqf account.

5. Cash waqf service.

This method is usually carried out by nadzir of waqf Tazakka during the boarding school activities or Sunday morning recitations held at the pesantren, cash, waqf can be through counters available on the porch of the mosque or in the office of LAZISWAF Tazakka.

6. Endowments Transfer Service.

This service is a method done by Tazakka for the person who wants to inherit his property through Tazakka's waqf account.

7. Collective Waqf Service.

Collective waqf services are also carried out by nadzir of waqf Tazakka for those who want to inherit their assets in groups, both in cash and non-cash. This is usually done by a sermon group who collectively distribute their cash waqf each month which is intended for land acquisition for expansion of the hut.

8. Tube Waqf (Tabung Wakaf) Services.

Tube waqf is a kind of deliberate box or piggy bank made by nadzir waqf of Tazakka so that the pilgrims who want to carry out their wealth in the form of coins can be facilitated. Because in the representation there is no minimum and maximum assets that will be represented. The waqf tube is given the slogan "one thousand one day" or "keep your change in the right place, because it can take you to heaven".

In the process of collecting waqf, nadzir launched several innovative and modernist endowments to explore the waqf potential of the Muslims from all forms of waqf. The endowments that have been formed and implemented by Tazakka include asset waqf, cash waqf, benefit transfer, endowments, and professional endowments. All kinds of waqf are managed and developed by Tazakka to support the development and progress of the Tazakka Modern Cottage and the welfare of the community.

The collection of waqf through a variety of waqf continued to experience a significant increase from 2012 to 2015 . The increase in the aspect of cash waqf collection in 2015 was dominated by the bleaching or elimination of the debt burden owned by Tazakka which later became a waqf for the continuity of the construction of the hut collection of waqf 
assets and material waqf is due to the large number of waqf who turn to cash waqf. The following is a graph of waqf collection by nadzir waqf of Tazakka:

Figure 1

Amount of Asset Waqf at Tazakka Boarding School

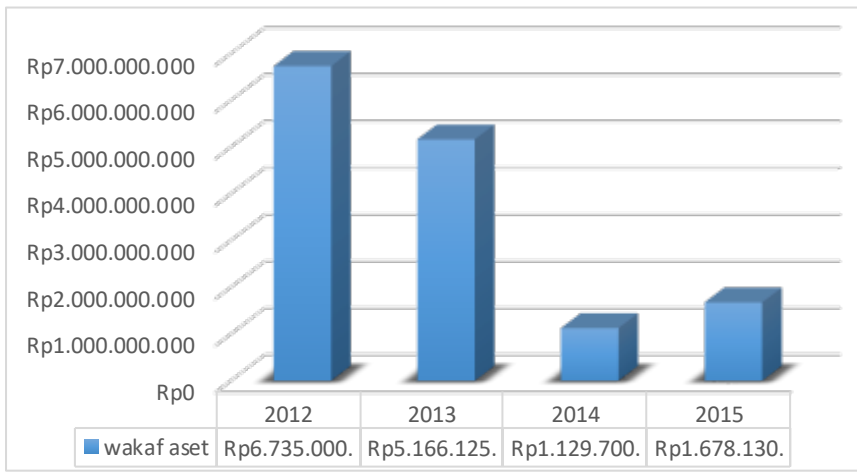

Source: report of Tazakea repot in 2015

Figure 2

Amount of Cash Waqf at Tazakka Boarding School

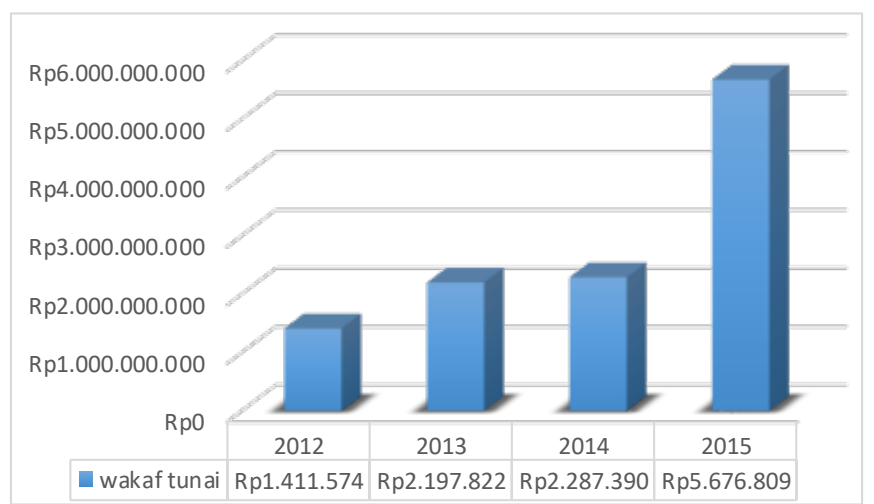

Source: report of Tazakeka repot in 2015 
ljtihad: Jurnal Wacana Hukum Islam dan Kemanusiaan, Volume 20, No. 1, Juni 2020: 1-21

Figure 3

Amount of Material Waqf at Tazakka Boarding School

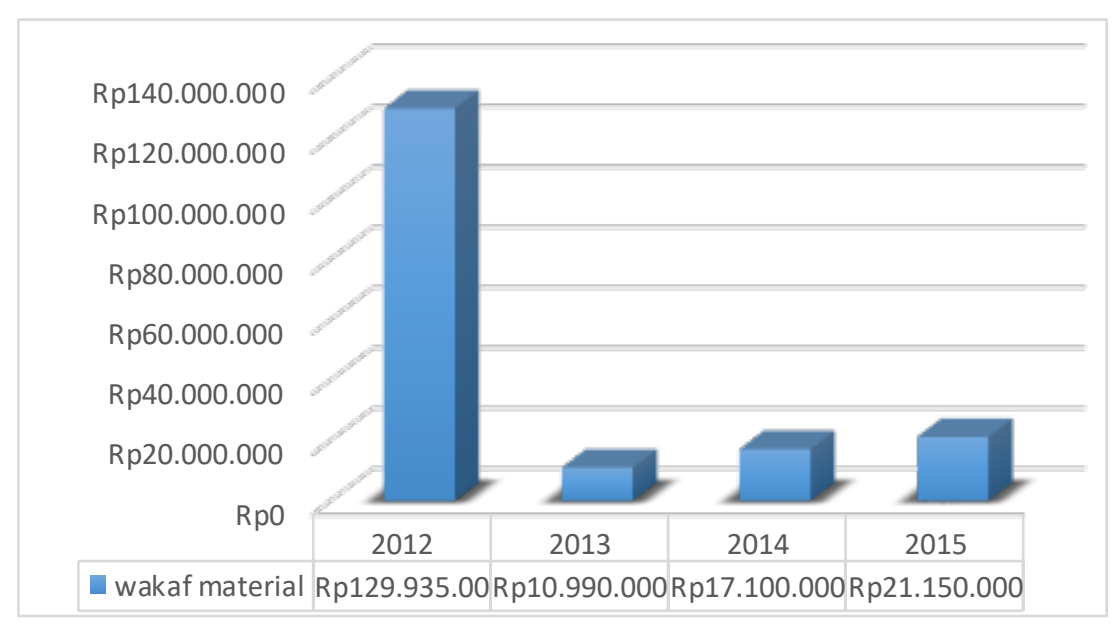

Source: report of Tazakka repot in 2015

In addition to cash waqf, assets and benefits, LAZISWAF Tazakka has also received many professional endowments and skills from a waqif. Here are the professions and expertise that are represented by the Tazakka Islamic boarding school. The professors of the profession usually endorse their expertise to assist in the continued development and progress of the boarding school. Example: A doctor who acknowledges his expertise to handle patients at Tazakka Medical Centre, an architect who designed and designed the site plan and the building of Tazakka Islamic Boarding School, a Notary who helped arrange official documents (Hudaya, 2016; Ardi, 2017). 
Figure 4

Profession Waqf at Tazakka Boarding School

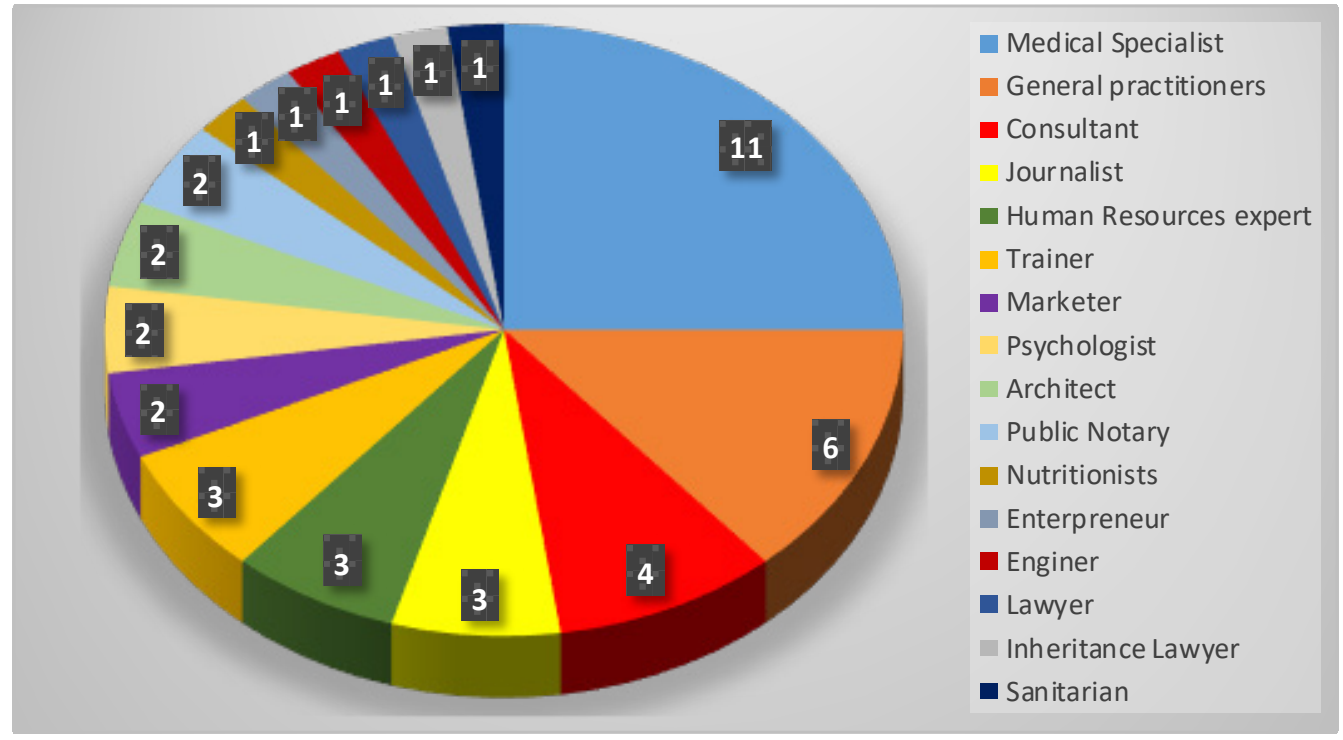

Source: report of Tazakek repot in 2015

Other kinds of waqf endowments is waqf benefits. Waqf benefits are carried out by someone who represents a movable or immovable object to take advantage of the object and is used for the benefit of the boarding school. Examples of some endowments that are represented by Tazakka are Villa Waqf, Hotel and Vehicle Rooms. Waqf benefits are nonprofit, so the waqf sincerely endow the object to be used by Tazakka. But if it is calculated in nominal terms, the benefits are estimated to reach billions of rupiah.

In carrying out their duties as nadzir waqf of Tazakka always strives to provide understanding to prospective instructors so that they truly understand waqf and the benefits obtained when someone is representing. Even though according to nadzir waqf itself that it is not really easy to invite donors and for nadzir himself it needs a long process. The strategy is like wanting to fish, so you need a fish pond. For this reason, LAZISWAF of Tazakka continues to update information to find donors or benefactors who will then introduce themselves, socialize waqf programs and benefits to donors. 
ljtihad: Jurnal Wacana Hukum Islam dan Kemanusiaan, Volume 20, No. 1, Juni 2020: 1-21

In each waqf fund collection, nadzir waqf will also provide a waqf certificate as proof that the waqif has given his wealth to Tazakka. The Money Waqf Certificate was issued by LAZISWAF of Tazakka for the beneficiary who has already granted the minimum cash of IDR 100,000.00 thousand. Nadzir also will facilitate the beneficiary of the treasure below that through evidence in the form of receipts. The proof of the certificate is as proof of the professionalism of nadzir of waqf Tazakka in managing waqf so that it is more accountable and transparent to the facilitators who need proof (Mahmassani, 2019).

\section{Effectiveness of fundraising waqf in realizing the independence of islamic boarding schools}

In empowering effective and efficient waqf management, nadzir of waqf has an important role in shaping waqf management strategies in a professional and integrity manner without prejudice to all applicable provisions, both statutory provisions and sharia provisions. Empowerment of good management must of course be based on an ideal concept in managing waqf. Judging from nadzir waqf of Tazakka's performance that nadzir has noticed four management functions in general, namely planning, organizing, implementing, and controlling.

1. Planning, namely nadzir formulates all boarding school development needs through the existence of various waqf managed by adjusting the vision and mission in the short, medium and long term owned by Tazakka so that waqf planning is in accordance with the wishes of Tazakka or waqif's own will.

2. Organizing, namely nadzir of waqf Tazakka is a private waqf institution under the foundation of Islamic boarding school of Tazakka. Nadzirin compiling an organization prioritized integrity, loyalty, and totality in every manager. All waqf administrators are Tazakka boarding school teachers who are given the mandate and responsibility by the head of the lodge as nadzir waqf of Tazakka.

3. Implementation, namely a stage where nadzir directs and controls all the results of the formulation and decision to carry out waqf management activities so that waqf objects can be in accordance with the planned so that the implementation process is in line with the vision and mission in the development of the cottage. 
4. Supervision, namely nadzir waqf of Tazakka carries out his responsibilities as nadzir as well as nadzir's professionalism in managing waqf. Nadzir's responsibilities include the report and coaching. In reporting, nadzir periodically reports to several parties, namely internal nadzir, head of the lodge and the government that handles waqf issues in this case is Indonesian Waqf Agency (BWI) and in the process of development, Tazakka opens guidance to worshipers and wakif through meetings or activities other huts.

The four management functions have been carried out as much as possible and managed so that the results of waqf management can achieve a vision that has been formulated together.

The concept of waqf management is that nadzir waqf of Tazakka has also fulfilled the criteria of ideal waqf management, namely the aspect of collecting waqf resources, in terms of productivity of waqf assets and in terms of empowering endowments. As described below:

1. Collection of waqf resources

Collection of waqf resources carried out by nadzir waqf of Tazakka divides into direct or indirect collection. The collection is managed through modern methods and waqf collection programs and adapts to the situation and development of the times. The collection of endowments in the form of cash waqf funds in Tazakka from 2012 to 2015 reached IDR 11,573,596,507 billion and for endowments assets reached IDR $14,708,955,000$ billion and material waqf of IDR 174,175,000 million. in comparison to the collection, cash waqf has increased from 2012 to 2015 while the waqf of assets and material waqf has decreased, this is due to the fact that many converts to cash waqf. The collection of cash waqf resources in 2016 and 2017 reached IDR 2,000,000,000 billion and for waqf collection in the form of endowments for transfer of rights, endowments of benefits and profession endowments also produced many benefits for the continuity of huts such as hospital services, important lodging guesthouses, design building, motivator, making legal documents and so on.

2. Productivity of waqf assets

The productivity of waqf assets is a form of development of waqf management so that the results of waqf can really be utilized and used to realize the benefit and 
improvement of the welfare of the people in a modern, transparent and responsible manner. In this case nadzir waqf of Tazakka manages endowments that have been collected for the development of huts and community welfare through established waqf programs. Currently the wakif funds that have been represented have been built in various types of buildings, ranging from mosques, learning buildings, santri dormitories, bathrooms, health clinics, and so on. In addition, nadzir waqf of Tazakka has also managed the endowments of the shop, the results of which will also be used for cottage development.

3. Empowerment of waqf results

As Tazakka has stated, Tazakka has a mission in the short, medium and long term. Through the programs that exist in each term, nadzir always formulates matters that can support the acceleration in the implementation of the program. All empowerment of waqf results is managed through good management and distribution in accordance with the objectives of the Sharia. Distribution of waqf results in the form of waqf empowerment is generally done by Tazakka for mawquf 'alaibi. Mawquf 'alaibi achieved what was intended was in the form of building boarding school infrastructure and also to improve the welfare of the community in the field of health in particular. Boarding school facilities and infrastructure are an important element in the sustainability of the boarding school as a place of education for the student (santri).

Nadzirwaqf of Tazakka continues to maximize the empowerment of waqf management, including through the methods used and innovative variety of endowments. At the same time, management of modern and advanced waqf can also increase awareness for the community that waqf is not only with land or objects that do not move, but the variety of waqf is very diverse and the methods used in empowering waqf management can also be managed by methods modern methods and adapt to the times. So that wakif can represent according to his wishes wherever and whenever, and with waqf it is expected to realize economic independence and prosperity for the community.

Empowerment of effective and optimal waqf management will certainly have great potential and opportunities in the development and progress of many sectors. The management of waqf in Tazakka Islamic Boarding School has great potential and 
opportunities in several sectors related to the development process and the sustainability of the lodge, namely:

1. Education sector, namely the construction of classrooms and dormitories and also the Tazakka Centre as a centre for education and training to support the continuity of education and regeneration for the student of Tazakka.

2. Health sector, namely the existence of a health clinic (Tazakka Medical Centre) which Tazakka built for health services for both santri, teachers and the surrounding community.

3. Economic sector, namely the existence of a canteen and Tazakka minimarket as a form of Tazakka's independence in managing the economy of the boarding school that is channelled to the continuity of the development and welfare of the lodge.

4. Welfare sector, namely with the construction of houses for teachers in Tazakka Islamic boarding school as a form of welfare for them for their service to the boarding school.

5. Da'wa and regeneration sector, that some Tazakka students selected as nadzir's partners are provided with knowledge and knowledge as a form of regeneration related to management of waqf management that is transparent and accountable in accordance with applicable rules. So that the santri will be able and brave to implement good and right waqf management when they go into the community. This is also one of the forms of preaching of the santri in introducing the potential and urgency of waqf to the wakif and the community.

\section{Conclusion}

After describing and discussing research on empowerment of waqf management in Tazakka Islamic borading school, the author draws the conclusion that nadzir waqf of Tazakka empowers waqf management through innovative varieties and waqf methods. The endowments that have been formed by nadzir waqf of Tazakka are endowments of money, endowments of assets, endowments of transfer of rights, endowments of benefits and professional endowments. The waqf variety is nadzir's way of mapping the types of waqf that will be collected from wakif through the process of collecting waqf. 
ljtihad: Jurnal Wacana Hukum Islam dan Kemanusiaan, Volume 20, No. 1, Juni 2020: 1-21

Waqf collection activities are very important for nadzir waqf of Tazakka. The collection of waqf is carried out through methods which are rarely carried out by nadzir waqf in general, are modern and advanced. The collection is divided into two types, namely direct and indirect collection. Direct collection is that waqifs are welcome to inherit their possessions by visiting the Tazakka boarding school directly or by picking up the ball by nadzir to the waqif address. Indirect collection is the time to endow the assets through waqf services, such as auto debit services, transfers to waqf accounts, waqf tubes, and others.

Empowerment of waqf management carried out by Tazakka boarding school has been well managed and directed in accordance with the management concept in general, namely through the process of planning, organizing, implementing, and monitoring. In addition, nadzir also regulates the concept of how to manage waqf effectively by taking into account the stages of collecting waqf resources, productivity of waqf assets and empowerment of waqf results in order to achieve optimal results.

The waqf funds that have been compiled and managed by nadzir waqf of Tazakka are distributed for the continuity of the development of the lodge in accordance with Tazakka's vision in the short, medium and long term such as the construction of santri dormitories, study rooms, bathrooms, and also to improve the welfare of the general public such as health clinics, shops, minimarkets and so on.

The potential for developing waqf management in Tazakka has a great opportunity to improve welfare for the wider community. For this reason, nadzir also needs to plan the management of productive waqf in other fields such as agriculture, animal husbandry, industry, and also as the end of money waqf through management by LKS-PWU. The results of productive endowments will have great benefits both for the development of the cottage and the welfare of the wider community. Also, For the government to continue to optimize the waqf management system that is effective and with integrity, so that representatives in Indonesia will continue to progress and develop to adjust the current conditions like other countries that have implemented waqf. 
Waqf fundraising strategy for islamic boarding's independence (Mohammad Noviani Ardi, dkk.)

\section{Bibliography}

Alabij, A Al. Perwakafan Tanah Di Indonesia Dalam Teori Dan Praktek, Jakarta: Rajawali Pers, 1989.

Ardi, Mohammad Noviani. "Strategi Fundraising Wakaf Pondok Modern Tazakka Batang”, Laporan Penelitian, Semarang: Unissula, 2017.

Aziz, Muhammad Ridhwan Ab., and Mohd Asyraf Yusof. "Examining the Relationship between Level of Income and Appointment of Agent in Collecting Waqf Fund." International Journal of Trade, Economics and Finance 5 (2) 2014: 167-69. https://doi. org/10.7763/ijtef.2014.v5.363.

Baidhawy, Z. Rekonstruksi Keadilan: Etika Sosial-Ekonomi Islam Untuk Kesejabteraan Universal. Salatiga: Stain Salatiga Press bekerjasama dengan JP Books, 2007.

Djunaidi, Achmad., and Thobieb Al-Asyhar. Menuju Era Wakaf Produktif: Sebuah Upaya Progresif Untuk Kesejabteraan Umat. Yogyakarta: Mitra Abadi Press, 2006.

Durroh, Nice. "Wakaf Diri Di Pondok Modern Darussalam Gontor Dalam Perspektif Fiqh Dan UU No.41 Tahun 2004.” Ejournal INSKLUSIF 1 (41) 2016: 1-29.

Efendi, Mansur. "Pelaksanaan Pasal 43 Undang-Undang Nomor 41 Tahun 2004 Mengenai Pengelolaan Harta Wakaf di Pondok Modern Darussalam Gontor." Al-Abkam: Jurnal Ilmu Syariah Dan Hukum 4 (2) 2019: 152-61.

Gontor, Balai Pendidikan Pondok Modern. Pekan Perkenalan di Kulliyatu-1-Mu'allimin AlIslamiyah Pondok Modern Gontor, Ponorogo, Indonesia: Diktat Kuliah Umum dalam Pekan Perkenalan Disampaikan oleh Direktur KMI, K. H. Imam Zarkasyi Sejak Th. 1939, dengan Beberapa Perbaikan dan Tambahan dari Ta, 1978.

Hidayatullah, Pusat Bahasa dan Budaya UIN Syarif. Berderma Untuk Semua Wacana Dan Praktik. Flantropi Islam. Pusat Bahasa dan Budaya, UIN Syarif Hidayatullah, 2003.

Huda, Miftahul. "Mekanisme Kerja Bersama Antara Nadzir Dan Lembaga Keuangan Syariah Penerima Wakaf Uang (LKS-PWU) Dalam Menggalang Wakaf Uang (Perspektif Manajemen Fundraising)." Jurnal Asy-Syir'ah 45 (I) 2011.

."Fundraising Wakaf Dan Kemandirian Pesantren: Strategi Nadzir Wakaf Pesantren Dalam Menggalang Sumber Daya Wakaf).” Intelegensia I (01) 2013a.

__."Model Manajemen Fundraising Wakaf." AHKAM : Jurnal Ilmu Syariab 13 (1) 2013b: 
ljtihad: Jurnal Wacana Hukum Islam dan Kemanusiaan, Volume 20, No. 1, Juni 2020: 1-21

31-38. https://doi.org/10.15408/ajis.v13i1.948.

—.Mengalirkan Manfaat Wakaf : Potret Perkembangan Hukum Dan Tata Kelola Wakaf Di Indonesia, Bekasi: Gramata Publishing, 2015.

Huda, Nurul. "Manajemen Pengelolaan Tanah Wakaf Di Majelis Wakaf Dan Zakat, Infaq, Shadaqah (ZIS) Pimpinan Daerah Muhammadiyah Kabupaten Malang." UIN Malang, 2009.

Hudaya, Muhammad Arif. "Pengembangan Wakaf Di Pondok Modern Tazkka Batang: Studi Terhadap Pemikiran KH. Anang Rikza Masyhadi.” Universitas Islam Indonesia Yogyakarta, 2016.

Ibrahim, Haslindar, Afizar Amir, and Tajul Ariffin Masron. "Cash Waqf: An Innovative Instrument for Economic Development." International Review of Social Sciences and Humanities. Vol. 6 2013. www.irssh.com.

Indonesia. Direktorat Pengembangan Zakat dan Wakaf. Strategi Pengembangan Wakaf Tunai Di Indonesia. Direktorat Pengembangan Zakat dan Wakaf, Direktorat Jenderal Bimbingan Masyarakat Islam dan Penyelenggaraan Haji, 2004.

Juwaini, Ahmad. Panduan Direct Mail Untuk Fundraising: Teknik Dan Kiat Sukses Menggalang Dana Malalui Surat / Ahmad Juwaini. Depok: Piramedia, 2005.

Md. Shahedur Rahaman Chowdhury. "Economics of Cash WAQF Management in Malaysia:

A Proposed Cash WAQF Model for Practitioners and Future Researchers." African Journal of Business Management 5 (30) 2011. https://doi.org/10.5897/ajbm11.1810.

Norton, Michael. Menggalang Dana: Penuntun Lembaga Swadaya Masyarakat Dan Organisasi Sukarela Di Negara-Negara Selatan. Jakarta: Yayasan Obor Indonesia, 2002.

Rozalinda. "Pengelolaan Wakaf Uang Di Indonesia: Studi Kasus Pada Tabung Wakaf Indonesia (TWI).” Annual Conference on Islamic Studies, no. November 2010: 1-4.

Suparman. "Strategi Fundraising Wakaf Uang." Jurnal Wakaf Dan Ekonomi Islam 2 (2) 2009. Sutisna, Hendra. Fundraising Database : Panduan Praktis Menyusun Fundraising Database Dengan Microsoft Access. Jakarta: Piramedia, 2008.

Tazakka, Pondok Modern. "Selayang Pandang." https://tazakka.or.id/2015/02/24/ selayang-pandang/. 2015.

Tjiptono, Fandy, and Anastasia Diana. Total Quality Management. Yogyakarta: Andi. 2003. 
Waqf fundraising strategy for islamic boarding's independence (Mohammad Noviani Ardi, dkk.)

Wakaf, Direktorat Pemberdayaan. Paradigma Baru Wakaf Di Indonesia. Jakarta: Direktorat Pemberdayaan Wakaf, Direktorat Jenderal Bimbingan Masyarakat Islam, Departemen Agma RI, 2007.

Widjajanti, Darwina. Rencana Strategis Fundraising. Jakarta: Piramedia, 2008.

Yacub, M. Pondok Pesantren Dan Pembangunan Masyarakat Desa. Bandung: Angkasa, 1985.

Zarkasyi, A S. Gontor \& Pembaharuan Pendidikan Pesantren. Divisi Buku Perguruan Tinggi, Jakarta: Raja Grafindo Persada, 2005. 
